\title{
A Study on the Spatial Abilities of Prospective Social Studies Teachers: A Mixed Method Research*
}

\author{
Eyüp Yurt ${ }^{1}$ \\ Gaziantep University
}

\author{
Vural Tünkler ${ }^{2}$ \\ Necmettin Erbakan University
}

\begin{abstract}
This study investigated prospective social studies teachers' spatial abilities. It was conducted with 234 prospective teachers attending Social Studies Teaching departments at Education Faculties of two universities in Central and Southern Anatolia. This study, designed according to the explanatory-sequential design, is a mixed research method, involving two stages. The first stage was conducted in the causal-comparative research design. The data were collected using "Mental Rotation Test" and "Surface Development Test". Descriptive statistics, MANOVA and ANOVA were used to analyze the data. The second stage was designed as a case study. "Opinion Form for Spatial Ability Tests" was used to elicit the views of 37 prospective teachers (F:20, M:17) identified via the purposive sampling method. The qualitative data obtained were analyzed using the content analysis technique. The study results showed that spatial visualization and mental rotation abilities of the prospective teachers were low; male prospective teachers were betterqualified than female ones in mental rotation but spatial visualization ability did not vary by gender. Moreover, prospective teachers with higher academic averages had better spatial abilities. Integrating virtual environment applications such as Google Earth etc. into social studies courses and using them in these courses can help to improve prospective teachers' spatial abilities.
\end{abstract}

\section{Keywords}

Spatial ability $\bullet$ Mental rotation $\bullet$ Spatial visualization $\bullet$ Social studies $\bullet$ Prospective teachers

\footnotetext{
* This study was presented as an oral presentation at the 3rd International Congress on Curriculum and Instruction, 2015, Adana, Turkey.

1 Correspondence to: Eyüp Yurt (PhD), Educational Science Department, Nizip Education Faculty, Gaziantep University, Gaziantep Turkey. Email: eyupyurt@gmail.com

2 Social Studies Education Department, Necmettin Erbakan University, Konya Turkey. Email: vtunkler@gmail.com

Citation: Yurt, E., \& Tünkler, V. (2016). A study on the spatial abilities of prospective social studies teachers: A mixed method research. Educational Sciences: Theory \& Practice, 16, 965-986.
} 
From the classical linguistic perspective, literacy refers to someone's ability to read, write, and speak in a language. These abilities can be observed in all parts of human life, ranging from everyday communications, to the workplace and science. In a similar vein, spatial literacy manifests itself in people's endeavors to solve problems in their lives, usually in the form of spatial knowledge, spatial thinking and acting patterns and spatial capabilities (National Research Council [NRC], 2006). Therefore, spatial thinking as a core skill of human life can be learned, incorporated into formal education, and enhanced through suitably arranged tools, technologies, and curricula.

Spatial ability is an important variable that guides students' academic achievements (Battista, Wheatley, \& Talsma, 1982; Lubinski, 2010; Maeda \& Yoon, 2013; Yurt, 2014). Studies conducted in this regard have revealed that spatial ability is correlated with higher order skills such as problem solving (Clements \& Battista, 1992; Hegarty \& Kozhevnikov, 1999; Kragten, Admiraal, \& Rijlaarsdam, 2015), creative thinking (Smith, 2009) and reasoning (Yurt, 2014). In addition, it has been understood that we use our spatial abilities effectively in daily life -for example, while using maps, doing sport and putting our things in order (Kimura, 1999; Peng, \& Sollervall, 2014; Pietsch \& Jansen, 2012). Thus, spatial thinking is felt very strongly in daily activities; however, it is difficult to filter out and know its role in these activities occurring in all aspects of people's lives. This kind of thinking is essential to many people's activities. It supports their successful performance and sometimes explains why a certain failure occurs (NRC, 2006).

Spatial ability is generally defined as the ability to form well-constructed visual shapes, keep them in mind, and arrange and convert them (Lohman, 1996). There is no consensus in the relevant literature about the components of spatial ability consists. Researchers have defined various components of spatial ability depending on their points of view based on the way they explain the mental processes used in the visualization of shapes. Although some of these components are common, many of them are quite different from one another. The components of spatial ability that have been defined and explained can be listed as space, spatial orientation, visualization, holistic (global) perception, holistic flexibility, speed of perception, estimate of length, perceptual changes and figurative delusions (French, 1951, p. 21 as cited in McGee, 1979); spatial visualization, spatial perception and mental rotation (Linn \& Petersen, 1985, p. 1482-1483); spatial orientation, spatial location memory, targeting, spatial visualization, differentiating objects and spatial perception (Kimura, 1999); visualization, spatial relations, speed of comprehension, mastery at comprehension and speed of perception (Carroll, 1993, p. 362-363) and spatial relations, visualization and spatial orientation (Contero et al., 2005, p. 25). On the other hand, spatial visualization and mental rotation abilities are generally regarded as the two fundamental components of spatial ability (Maeda \& Yoon, 2013). Spatial 
visualization has been defined as being able to imagine the holistic and step by step orientations of objects and parts of objects in a three-dimensional space (Olkun, 2003), whereas mental rotation has been defined as the ability to invert and rotate two and three-dimensional objects in mind (Carroll, 1993).

Studies aimed at identifying individual differences in spatial ability have revealed that spatial ability might differ by gender (Casey, Nuttall, Pezaris, \& Benbow, 1995; Linn \& Petersen, 1985; Maeda \& Yoon, 2013; Reilly \& Neumann, 2013; Turğut \& Yenilmez, 2012; Yurt \& Sünbül, 2011). It has transpired as a result of many studies indicating that males are more talented than females, especially in the mental rotation ability. Meta-analysis studies conducted in recent years are in support of this view (Maeda \& Yoon, 2013; Reilly \& Neumann, 2013). Maeda and Yoon (2013) brought together the findings of 40 studies using the meta-analysis method in order to investigate the effect of gender on the three-dimensional mental rotation ability. The research groups of the studies investigated contained an extensive audience of participants ranging from fifth graders to university students. According to the findings obtained as a result of the meta-analysis, boys' performance in the mental rotation test was better than girls'. It was found that as the time allocated to answer the threedimensional mental rotation test decreased, gender difference increased. In another meta-analysis study, Reilly and Neumann (2013) investigated the differences in the mental rotation ability in the context of gender role. 14 studies conducted in England, Poland, Croatia and the United States of America were investigated using the metaanalysis method. As a result of the study, the correlation between masculinity with the girls' mental rotation performance was calculated to be $r=.23$, whereas its correlation with boys' mental rotation performance was calculated to be $r=.30$. On the other hand, no correlation was found between femininity and mental rotation performance.

In studies conducted in the relevant literature, positive and significant correlations were found between spatial ability and achievement in disciplines such as Physics (Kozhevnikov, Motes, \& Hegarty, 2007; Delialioğlu \& Aşkar, 1999), Chemistry (Stieff, Ryu, Dixon, \& Hegarty, 2012; Wu \& Shah, 2004), Mathematics (Casey, Nutall, \& Pezaris, 2001; Cheng \& Mix, 2014; Kyttälä, Aunio, Lehto, Van Luit, \& Hautamäki, 2003; Yurt, 2014); and Geometry (Battista, 1990; Hannafin, Truxaw, Vermillion, \& Liu, 2008). Moreover, it was stated that spatial ability was a very important and fundamental ability to do well in departments of Science, Technology, Engineering, Mathematics, and Geography, (Lubinski, 2010; NRC, 2006) and have an academic career in these departments (Uttal \& Cohen, 2012). It is observed that activities are organized to improve spatial ability at primary school (Yıldız, 2009), middle school (Yurt \& Sünbül, 2012), high school (Karaaslan, 2013) and university level (Rafi, Samsudin, \& Ismail, 2006) due to the importance of spatial ability. 
One of the school subjects that requires spatial ability and where spatial ability is used effectively is social studies. Spatial ability is needed in the social studies class especially while using a map, drawing a sketch and picturing facts and phenomena in mind threedimensionally (Ministry of National Education [MNE], 2005). When the curriculum of the social studies course is examined, it is seen that the importance of spatial ability is explained as the skill to perceive a space. At the same time, it is also emphasized in the program that the skill to perceive space is associated with spatial ability. According to this, by using their spatial ability, students can, $i$ )Picture in their minds the shape of an object in space or a figure on paper, $i$ ) see a figure three-dimensionally and iii)picture an area, a sketch, a street or a building in their minds. In this respect, it is emphasized that spatial ability is very important to be able to express the space in different ways, perceive and express the elements present in the environment, create drawings with regard to space and interpret these drawings (MNE, 2005).

The 4th-grade activity visual given in Figure 1 can be examined to better understand how to use spatial ability in social studies courses. In the activity, the teacher asks students to imagine that they are working on the observation deck at the airport. A

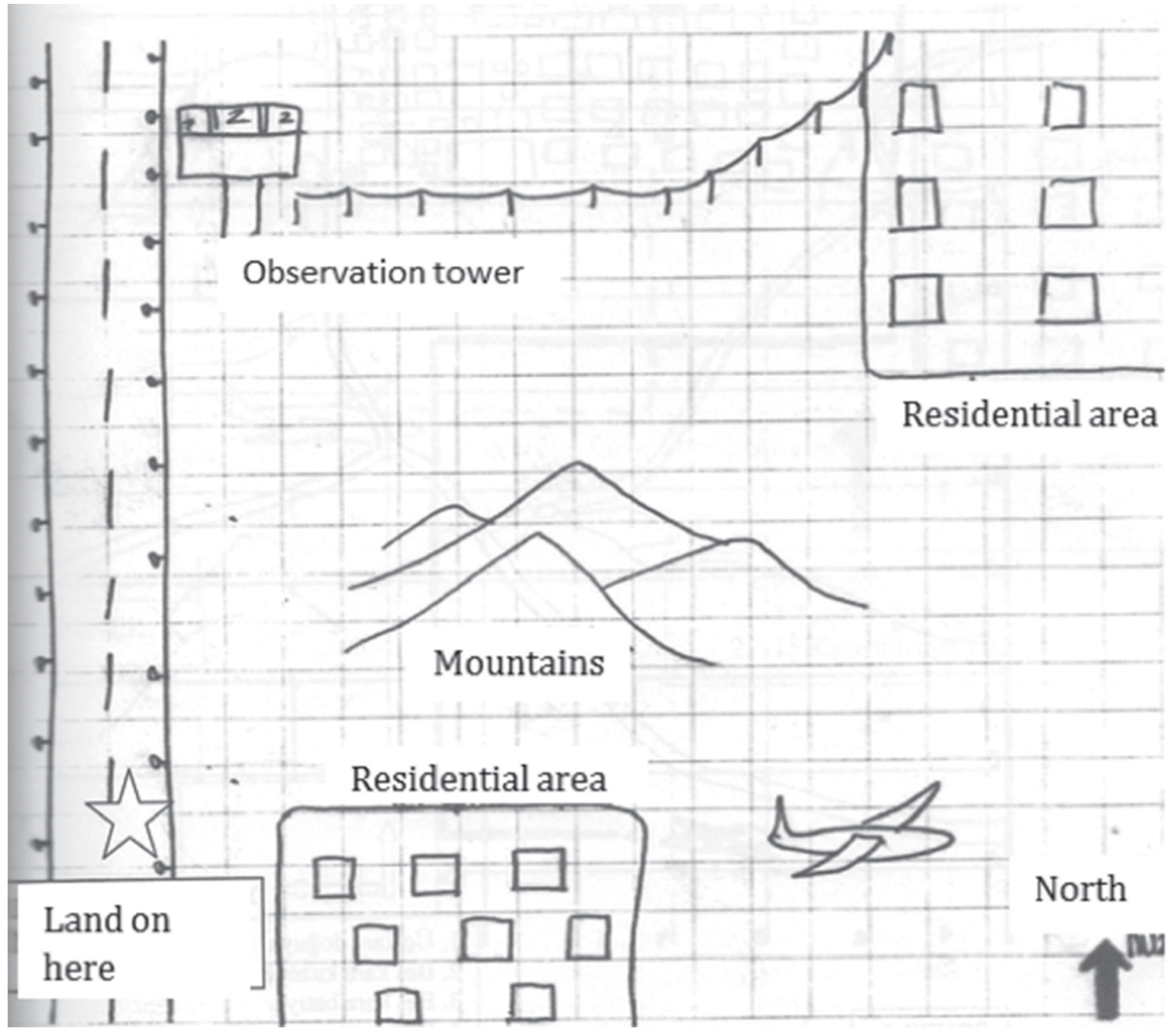

Figure 1. Sample Activity (MNE, 2005, p. 197). 
pilot wants help from the observation deck to land the plane. The students, in this activity, need to help the plane to land safely without going through the residential area, the mountains, and electric wires. The students are supposed to give accurate instructions to the pilot in order to land the plane safely. To do this, the students can read the map and find accurate directions on the map. Wayfinding, showing the ways and orienteering are closely related to mental rotation ability (Kozhevnikov, Motes, Rasch, \& Blajenkova, 2006; Malinowski, 2001). On the other hand, forming the sketch used in the activity is associated with spatial visualization ability. As can be seen in the activity, spatial ability becomes effective in students' carrying out the activity successfully by functioning behind the stage.

The level of spatial ability of prospective social studies teachers, who will teach students the skill to perceive space as stated in the socials curriculum, is extremely important. Social studies prospective teachers' being able to draw and convey the concrete and three-dimensional facts and phenomena they see around and their being able to picture in their minds true and three-dimensional figures by looking at the drawings is closely related to their spatial abilities. It is seen in the relevant literature that studies investigating pre-service teachers' spatial abilities focus on Mathematics pre-service teachers (Bulut \& Köroğlu, 2000; Göktepe \& Özdemir, 2013; Turgut \& Yilmaz, 2012; Turğut \& Yenilmez, 2012; Unal, Jakubowski, \& Corey, 2009). No study has been found investigating the spatial abilities of social studies prospective teachers. However, spatial ability, which is used in daily life and in many occupational fields, is essential for all disciplines. In this respect, it is quite important to determine the spatial ability levels of social studies prospective teachers and the factors affecting their spatial abilities. In this way, it may be possible to prepare more qualified course contents with regard to some practical subjects included in the social studies teaching curriculum. The findings that will be obtained can contribute, especially, to more effective planning of the teaching processes of some skills such as describing threedimensional forms, using maps and drawing sketches. Answers were sought to the following questions in accordance with the overall objective of the study;

1- What is the level of mental rotation and spatial visualization abilities of the students who participated in the study?

2- Do the mental rotation and spatial visualization abilities of the students who participated in the study vary by gender and their achievement levels?

3- What are the views of the students who participated in the study concerning spatial ability tests? 


\section{Method}

Explanatory sequential design, one of the mixed method research types, was used in this study. Explanatory sequential design is a research design where qualitative data are collected and analyzed following the collection and analysis of the quantitative data, thereby allowing detailed analysis of quantitative data (Creswell, 2012). "Causal comparative design, which is one of the quantitative research approaches, was used in the quantitative dimension of the study. Causal comparison is a research design that compares existing differences among groups before observations of researchers (Suter, 2006) and enables identification of the cause and effect relationships between dependent and independent variables (Büyüköztürk, Çakmak, Akgün, Karadeniz, \& Demirel, 2012). The independent variables of this study involve gender and general academic average. The independent variable, on the other hand, is prospective teachers' spatial ability levels.

The qualitative dimension of the study was planned according to the "case study design." Case study is a qualitative research design that focuses on investigating a single person or organization using a wide range of data (Suter, 2006). The element that determines the characteristic of this design and defines the case is the "unit of analysis" (Merriam, 2013). Prospective teachers are the unit of analysis in this study. The reason why case study was used in this research was that it was intended to better understand the research problem by delving deeper into the quantitative data. The document review method was used as the data collection tool in this study, which was designed according to the case study design. Document review is a data collection method that involves analysis of written materials containing information about event(s) or phenomenon/phenomena (Yıldırım \& Şimşek, 2011).

\section{Research Group}

The research group of the quantitative dimension of the study consisted of 234 second and third year university students attending the Social Studies Teaching department at two education faculties in Central and Southern Anatolia in the spring semester of the 2014-2015academic year. The criteria employed in the selection of the participants were as follows: "Having received the Physical Geography of Turkey offered in the second year of Social Studies Teaching department, having received, within this course, education of drawing maps and being able to look at maps from different angles, and participating in the study voluntarily". In this framework, second and third year students at university were included in the study whereas fourth year students did not participate in the study as they were preparing for the Public Personnel Selection Examination. $54.7 \%(n=128)$ of the students were female whereas 45.3 $\%(n=106)$ were male. $45.7 \%(n=107)$ of the students were in their second year while $54.3 \%(n=127)$ were in their third year. The research group of the qualitative dimension of the study, on the other hand, consisted of 37 prospective teachers $(F=20$, 
$M=17$ ) who were selected using the purposive sampling method due to the fact that we aimed to select participants with certain qualities. The criteria employed during the selection process of the participants were "their levels of achievement in spatial ability tests (poor-intermediate-high)" and "volunteering to participate in the study".

\section{Data Collection Instruments}

Three kinds of data collection instruments were used to attain the purpose of the study. The data collection instruments used were listed below in the form of sub-headings.

Mental Rotation Test. In order to measure the mental rotation skills of students in the research group, the Mental Rotation Test, which was developed by Vanderberg and Kuse (1978), revised by Peters et al. (1995) and adapted to Turkish by Yildiz (2009), was used. The Mental Rotation Test consists of 24 questions. The quality of each question on the test is the same. In each question, the participants are asked to find two forms that are the same as the figure given in the far left, but to display its images from different directions and angles. In order to be able to answer the questions, students need to be able to picture in their minds different images of the given three-dimensional figures (Figure 2). In the scoring of the test, 1 point is given for each pair of correct figures and 0 point is given in other cases. The maximum score that could be received from the test is 24 and the minimum score is 0. High scores indicate high mental rotation ability. Mental rotation test is at the same time a speed test and the time allocated for doing the test takes about 16 minutes. The internal consistency coefficient of this study was calculated to be $.72(n=234)$.
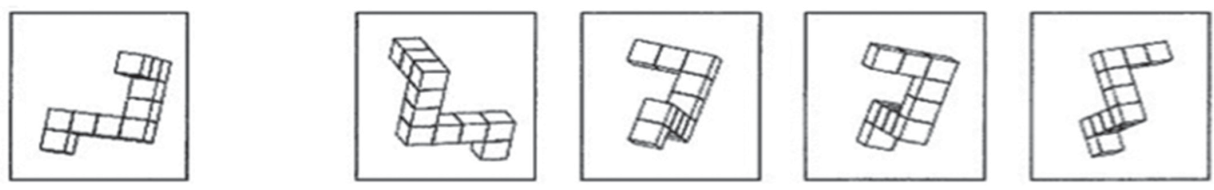

Figure 2. A sample mental rotation question.

Surface Development Test. In order to measure students' spatial visualization abilities, The Surface Development Test, which was developed by Ekstrom, French, Harman, and Dermen (1976) was used. The test contains 12 questions. Each question requires students to match the edges of a shape to the edges of the shape when it is folded up along the dotted lines of a shape. In order to be able to solve the problems, one should be able to visualize the open and closed forms of the shape (Figure 3). In the scoring of the test, 1 point is given for each correct answer but no points are given for incorrect answers. The maximum score that could be received from the test is 60 and the minimum score is 0 . High scores indicate high spatial visualization abilities. The surface development test is at the same time a speed test and the administration of test takes about 24 minutes. The internal consistency coefficient of this study was calculated to be $.75(\mathrm{n}=234)$. 

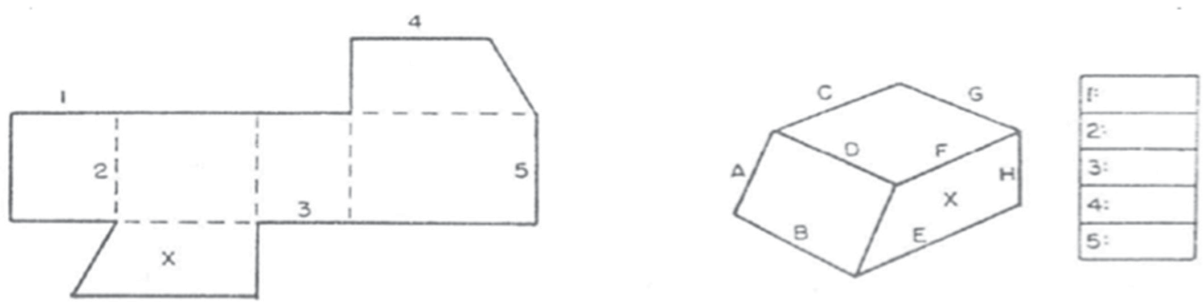

Figure 3. A sample surface development test question.

Demographic information form. The demographic information form was used to obtain the participating students' genders, classes and grade point averages. The demographic information form included choices where the students could express their genders and classes. In addition, the students were also asked to state their grade point averages on the form. The students' grade point averages and their median were calculated as 2.75, and their mode as 2.5.The academic achievement levels of students whose grade point averages were below 2.5 were designated as low, the academic achievement levels of students whose grade point averages were between $2.5 \leq$ and $<3.0$ were designated as intermediate and those above 3.0 and above were designated as advanced.

Opinion Form for Spatial Ability Tests (OFSAT). The opinion form for spatial ability tests is a form that was developed by the researchers making use of the studies on spatial thinking ability and contains three questions (including the probe questions). Initially, "probe questions" were added to the form by taking views of experts ( 2 experts, one social studies teaching expert and the other education sciences expert) with regard to the draft form and then the form was given its final form. OFSAT contains questions and probes like "What are your opinions about spatial ability tests? Explain.”.

OFSAT was administered on the same day to 5 groups ( 4 consisting of 8 students and 1 consisting of 5 students, in total 37 students) for about 30 to 40 minutes. The following procedure was used in the administration of the form:

OFSAT was first distributed to prospective teachers and they were asked to complete the form. After the necessary information was given to the prospective teachers regarding the overall purpose of the study, a general explanation was made concerning the questions on the form and it was emphasized that if they encountered questions they had difficulty with, they could ask for help. Moreover, it was intended that prospective teachers give sound (clear and detailed) responses to the questions by reflecting the spatial ability tests on a wall by the help of an overhead projector. 


\section{Analysis of the Data}

Descriptive statistics and univariate and multivariate variance analyses were used to analyze the quantitative data of the study. Before the analyses were conducted, it was investigated whether or not univariate and multivariate normal distributions hypotheses were met. To this end, first coefficients of skewness were calculated and the distribution of each of the dependent variables according to the independent variable groups was investigated. It was found that the coefficients of skewness took values varying between 0 and 1 and that the hypothesis of univariate normal distribution was met (George \& Mallery, 2003). Then, Mahalanobis distance values were calculated and no values were met marring the multivariate normal distribution $\left(\otimes_{(2)}=13.82 ; p<.001\right)$. On the other hand, value ranges recommended by Cohen (1988) were used to interpret the effect size values obtained in the study. According to Cohen's classification (1988), it demonstrates a "small" effect when it is $\mathrm{d}=.02$, a "medium" effect when it is $d=.05$ and a "big" effect when it is $d=.08$. The analyses in the study were performed using SPSS 18.0 package software program.

The "content analysis" technique was used to analyze the qualitative data of the study. Content analysis is the process of conceptualization of the data obtained by performing an in-depth analysis of them, organizing them in a logical manner and reaching themes that explain the data (Y1ldırım \& Şimşek, 2011). The fundamental purpose of the content analysis method is to "reach concepts and relationships that could explain the data that were collected.” (Yıldırım \& Şimşek, 2011, p. 227). During the process of analysis, the opinions which the participants expressed with regard to the spatial ability tests (the surface development test-the mental rotation test) were encoded, then themes that could subsume these codes under certain themes were found that finally the findings obtained were interpreted. The themes in the study were formed on the basis of the responses which the participants gave to the questions on the Opinion Form for Spatial Ability Tests. In the data analysis process, the themes "facility-difficulty of spatial ability tests (mental rotation test-surface development test)" and "methods used in answering spatial ability tests" emerged. The model presented in Figure 4 is developed in accordance with "facility-difficulty of spatial ability tests" theme. In the study, when exact citations were made from the opinions of the participants, the statements that did not match the theme were not indicated; instead, ellipsis mark (...) was used. An encoding system was made use of when exact citations were made from the participants' opinions. The encoding system was as follows: "Participant (P), Gender (for female: F, for male M) and the number of the participant (like 1-2-3-4)". For example; PF1= Participant Female 1; PM7= Participant Male 7.

Exact citations were made from the opinions of the participants in order to ensure the validity of the study. Making direct citations from the opinions of the participants and explain the results is important for validity (Yıldırım \& Şimşek, 2011). On 
the other hand, another researcher's help was enlisted in ensuring the reliability of the study. Reliability "involves using another researcher in the analysis of the data obtained and confirming the results reached. In this way, it can be confirmed that the results reached are based on the data obtained rather than the personal opinion of the researcher." (Yıldırım \& Şimşek, 2011, p. 263). Another way of ensuring reliability in qualitative studies is to provide transparency by making detailed explanations about how the study has been conducted (Güler, Halıcığlu, \& Taşğın, 2013). In this present study, too, an attempt was made to describe in detail the stages of qualitative data collection and data analysis.

\section{Findings}

One-way MANOVA was performed to determine whether or not social studies prospective teachers' mental rotation and surface development mean scores varied by class level, gender and academic average. The results obtained are given in Table 1 and in Table 2.

\begin{tabular}{|c|c|c|c|c|c|c|}
\hline $\begin{array}{l}\text { Table } 1 \\
\text { Mental Rotation an } \\
\text { Prospective Teacher }\end{array}$ & $\begin{array}{l}\text { urface Devel } \\
\text { According to }\end{array}$ & $\begin{array}{l}\text { Test } 1 \\
\text { nder }\end{array}$ & $\begin{array}{l}\text { res ar } \\
\text { ademi }\end{array}$ & $\begin{array}{l}\text { lard L } \\
\text { ges }\end{array}$ & s of $S$ & dies \\
\hline & & & Men & ation & Spatial & ization \\
\hline Varıables & & $\mathrm{N}$ & $\bar{X}$ & $\mathrm{Sd}$ & $\bar{X}$ & $\mathrm{Sd}$ \\
\hline & Female & 128 & 6.95 & 3.79 & 23.84 & 11.77 \\
\hline Gender & Male & 106 & 8.94 & 4.57 & 22.02 & 12.02 \\
\hline & Low & 63 & 7.17 & 3.48 & 19.22 & 10.24 \\
\hline Academic Average & Intermediate & 121 & 8.00 & 4.59 & 23.76 & 11.79 \\
\hline & High & 50 & 8.36 & 4.34 & 25.98 & 13.05 \\
\hline General & & 234 & 7.85 & 4.27 & 23.01 & 11.89 \\
\hline
\end{tabular}

According to Table 1, it is seen that male prospective teachers' mental rotation mean scores are higher, whereas female prospective teachers' surface development mean scores are higher. Moreover, prospective teachers with high academic achievement levels have higher mental rotation and surface development scores. In addition, mental rotation and surface development mean scores of the prospective teachers who participated in the study are quite low.

\begin{tabular}{|c|c|c|c|c|c|c|}
\hline \multicolumn{7}{|c|}{$\begin{array}{l}\text { Table } 2 \\
\text { Results of MANOVA Applied to the Mental Rotation and Surface Development Mean Scores of the Social } \\
\text { Studies Prospective Teachers According to Their Genders and Academic Achievements }\end{array}$} \\
\hline Independent variable & $\lambda$ & $\mathrm{F}$ & Hypothesis Sd & Error $\mathrm{Sd}$ & $\mathrm{p}$ & $\eta 2$ \\
\hline Gender & .901 & 12.54 & 2 & 227 & .000 & .10 \\
\hline Academic Achievement & .949 & 3.00 & 4 & 454 & .018 & .03 \\
\hline
\end{tabular}

According to Table 2, it is understood that mental rotation and surface development mean scores of the social studies prospective teachers varied by their genders and 
academic achievements. Moreover, it is observed that gender has a large effect on spatial ability whereas academic achievement has a medium level effect on it. Finally, ANOVA was conducted to see what dependent variable or variables contributed to multivariate significance. The results obtained are given in Table 3.

\begin{tabular}{|c|c|c|c|c|c|c|c|}
\hline \multicolumn{8}{|c|}{$\begin{array}{l}\text { Table } 3 \\
\text { Results of ANOVA Applied to the Mental Rotation and Surface Development Mean Scores of the Social } \\
\text { Studies Prospective Teachers According to Their Genders and Academic Averages }\end{array}$} \\
\hline Source of the Variance & Dependent Variable & Mean Squares & $\mathrm{Sd}$ & $\mathrm{F}$ & $\mathrm{P}$ & $\eta^{2}$ & Statistical Power \\
\hline \multirow{2}{*}{ Gender } & Mental Rotation & 329.56 & 1 & 19.57 & .000 & .08 & .99 \\
\hline & Surface Development & 9.15 & 1 & .07 & .797 & .00 & .06 \\
\hline \multirow{2}{*}{ Academic Average } & Mental Rotation & 78.61 & 2 & 4.69 & .010 & .04 & .78 \\
\hline & Surface Development & 546.45 & 2 & 3.96 & .020 & .03 & .71 \\
\hline
\end{tabular}

According to Table 3, it is understood that prospective teachers' mental rotation mean scores varied by gender $\left(\mathrm{F}_{(1-228)}=19.57, p<.001\right)$ but surface development mean scores did not vary $\left(\mathrm{F}_{(1-228)}=.07, p>.05\right)$. When female and male prospective teachers' mental rotation mean scores are examined, it is understood that male prospective teachers' mental rotation mean scores are higher $(\bar{X}=8.94)$ than female prospective teachers' $(\bar{X}=6.95)$. At the same time, it is seen that gender has a largescale effect on mental rotation ability $\left(\eta^{2}=.08\right)$.

Moreover, According to Table 3, it is seen that the scores which the prospective teachers received from the mental rotation $\left(\mathrm{F}_{(2-228)}=4.69, p<.05\right)$ and surface development $\left(\mathrm{F}_{(2-22)}=3.96, p<.05\right)$ tests varied by their academic achievements. According to Bonferroni multiple comparison test, it was understood that both the mental rotation and surface development test scores of the prospective teachers with high academic achievement levels were higher in comparison with the prospective teachers having low academic achievement levels. Furthermore, it is observed that academic average has a medium level effect on mental rotation and surface development skills $\left(\eta^{2}=.04\right)$.

In order to find an answer to the problem "What are the opinions of the students participating in the study regarding spatial ability tests?" which is the third subproblem of the study, the views which the social studies prospective teachers expressed with regard to the questions on the Opinion Form for Spatial Ability Tests were subjected to content analysis.

Data analysis indicated that prospective social studies teachers' opinions on using spatial ability tests focused on the themes "facility-difficulty of spatial ability tests (mental rotation test-surface development test)" and "methods used in answering spatial ability tests". The facility-difficulty of spatial ability tests theme is presented in Figure 4. 

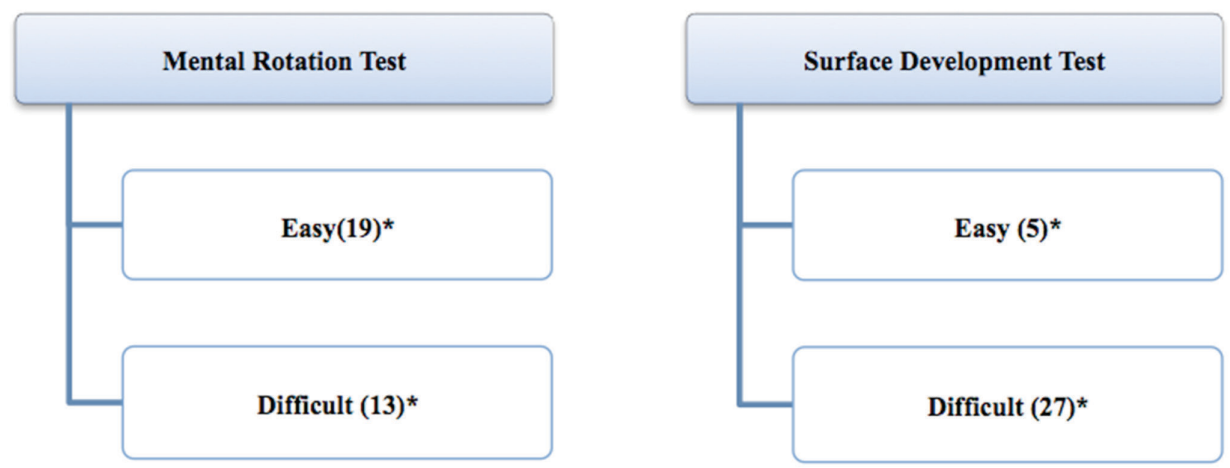

Figure 4. Social studies prospective teachers' opinions regarding facility and difficulty of spatial ability tests.

Facility-difficulty of spatial ability tests. Figure 4 shows the distribution of the prospective teachers' opinions concerning the facility and difficulty of spatial ability tests. When Figure 3 is examined, it is seen that prospective teachers perceive the mental rotation test as easy whereas they generally regard the surface development test as difficulty. On the other hand, when the distribution by gender of the participants' opinions regarding the both tests is examined, it is observed that male prospective teachers found the mental rotation test easier compared with the female prospective teachers and that female prospective teachers' opinions with respect to the mental rotation test concentrated mostly on its difficulty. When the participants' opinions concerning the surface development test were taken into consideration, it was found that the opinions of the male and female prospective teachers with regard to this test were close to one another and that both genders stated that the test was difficult. Values regarding the facility and difficulty of the spatial ability tests and the frequency values concerning the distribution of the participants by their gender are given in Table 4.

Table 4

Distribution the Opinions of the Students Concerning the Facility and Difficulty of Spatial Ability Tests by Gender

\begin{tabular}{lcc}
\hline \multirow{2}{*}{ Spatial Ability Test } & \multicolumn{2}{c}{ Gender } \\
\cline { 2 - 3 } & Female & Male \\
\hline Mental Rotation Test-Easy & 8 & 11 \\
Mental Rotation Test-Difficult & 10 & 3 \\
Surface Development Test-Easy & 3 & 2 \\
Surface Development Test-Difficulty & 14 & 13 \\
\hline
\end{tabular}

When the opinions of the prospective teachers regarding the mental rotation test are examined, it is understood that some of the prospective teachers expressed positive opinions whereas others expressed negative opinions; that the prospective teachers who expressed positive opinions found the test good fun, did not experience difficulty in mental visualization and rotation, whereas those who expressed the opposite opinions experienced mental fatigue while they were doing the test and 
had difficulty finding the two shapes belonging to the object as the shapes in the test resembled one another. The opinions of some of the prospective teachers who became reference points for this theme are given below:

I really liked the mental rotation test. Initially, I lost some time trying to figure out the logic behind it but once I grasped its rationale, I realized that it was very easy and answered it within a short time. That is, in my opinion, the mental rotation test was easier and clearer. (PM24)

As far as I am concerned, the mental rotation test was, of course, easier than the other one; there were points where I had difficulty but in a quite environment and when I was able to give my full attention, I tried to rotate them in my mind easily. (PM28)

I was surprised by the practice but I found it enjoyable because it led me to think threedimensionally. The mental rotation test was easy and pleasurable form e. Also, I did it without getting bored. (PF25)

The mental rotation test was easy for me. I was able to see how the shape could rotate. It was easy for me to visualize; only, I had to identify its direction. (PF15)

The fact that the shapes in the mental rotation test were very similar to one another further increased my mental fatigue. Sometimes, although I had found the right answer, I was confused by the possibility that one of the others could also be correct. I realized that my brain had grown tired and I had difficulty perceiving properly. (PF1)

..... I had difficulty in doing the other test, namely the Mental Rotation Test because there were no instructions like " $x$ ". Indeed, I was not even sure about whether most of my answers were right or wrong. There were times when I could not choose from among the choices. (PF6)

I experienced difficulties in both tests. I had difficulty visualizing the shapes accurately. (PM7)

They were tests that required considerable attention and multidimensional thinking skills. To be honest, they were quite difficult for me. (PM33)

When the prospective teachers' opinions concerning the surface development test are examined, it is seen that prospective teachers have positive and negative opinions with respect to this test. It is understood that the prospective teachers who expressed positive opinions did not experience difficulty in solving the test as the instructions given in the test guided them and also their areas of occupation in daily life helped them in solving the problem; on the other hand, a look at statements of the prospective teachers who expressed negative opinions indicates that they could not visualize the shapes in their minds and therefore could not perform mental folding; also, the degree of difficulty increased in the. Some of the opinions of the prospective teachers who served as reference points with regard to this theme are given below: 
Although I did not experience difficulty with the surface development test initially, I began to have difficulty towards the end. Initially, I was able to do the test in my mind but I started to experience difficulty towards the end and began to fail. (PM16)

The surface development test, on the other hand, was more difficult for me because it was the first time I had encountered such a practice. As the questions progressed, I noticed that my thinking style changed but the questions had begun to get difficult in parallel to this. Therefore, I can say that I had difficulty in the surface development test. (PM28)

I had huge difficulty in the surface development test as I could not match the open and folded versions of the shape. (PF34)

I had more difficulty in the surface development test than in the other one, because I was not able to visualize what the shapes would be like when they were folded. (PF4)

I had less difficulty in the surface development test than in the other one but I had problems with the time allocated while I was working on some shapes because those shapes had too many details and I was in a dilemma about what letter corresponded to what number. All the same, surface development test was much easier. (PF1)

Of the tests done, I did not experience difficulty in the Surface Development test because we had been given the necessary instructions. It had been shown that the front side was " $x$ ". Therefore, it was much easier to develop the surface according to the front side. (PF6)

For me, it was not difficult .... because I engage in a job in my daily life which requires me to think three-dimensionally. (PM13)

I believe that if the test had been a little shorter, I would have had more correct answers because I was confused about the questions and I could not concentrate properly. Other than that, the questions were not difficulty, I think. (PM14)

The other theme which emerged as a result of prospective social studies teachers' opinions regarding spatial ability tests was "methods used in answering spatial ability tests" theme. It was revealed in the interviews with prospective teachers that they had difficulty in answering the surface development test and tried different ways to answer the questions. Given the low scores taken by prospective teachers on the tests, it may be suggested that the methods which prospective teachers used to answer the tests were not sufficient or effective. Some prospective teachers commented on the surface development tests as follows:

When I started to answer the questions, first of all, I tried to copy the figures to my mind. I had a very hard time in the first test, and I tried to combine the figures by moving my head. However, after combining two figures, my head did stop when it came to the third one. Later on, I drew the two figures on the paper. (PM8) 
In the surface development test, I firstly tended to fold up the paper, but I could not imagine it. After that, I tried to reach the result by drawing the figure, placing $\mathrm{x}$ in the center. (PF18)

I thought how the figure can be made in the surface development. Then I pondered over which edges touch the surface and which ones fall to the other side by painting the marked surface. (PF15)

... But, in the last phase, as the degree of difficulty increased, I folded up the figure with my fingertips as I did in the previous test. (PF25)

In the mental rotation test, I counted how many boxes were in the vertical and horizontal areas initially. (PF1)

It was easy to understand the figure turned in the mental rotation test. I determined to what way the cubes raised, and in what way the raised side would be. (PF15)

When I could not visualize the figure in my mind and understand its meaning, I took the paper and turned it until I found the accurate answer. (PF25)

I turned the paper while answering the mental rotation test. (PF35)

\section{Conclusion and Discussion}

In this study, spatial abilities of social studies prospective teachers were investigated multidimensionally using quantitative and qualitative research methods together. According to the results obtained, it was understood that social studies prospective teachers' spatial visualization and mental rotations abilities were at a low level. The results of the study are in parallel with the studies in the relevant literature. The results of the study who were conducted on students who received their education at the Faculty of Education in different fields such as natural sciences, social sciences, foreign languages and visual arts indicated that the spatial visualization and mental rotation abilities of the education faculty students were at a rather low level (Yurt \& Sünbül, 2011). Similar results were obtained in studies conducted on Mathematics pre-service teachers. According to this, it was found that Mathematics pre-service teachers' spatial orientation (Bulut \& Köroğlu, 2000; Turgut \& Yilmaz, 2012), spatial visualization (Bulut \& Köroğlu, 2000; Cantürk-Günhan, Turgut, \& Y1lmaz, 2009; Göktepe \& Özdemir, 2013; Turğut \& Yenilmez, 2012) and mental rotation (CantürkGünhan et al., 2009) abilities were at a low level.

The results obtained in this study can be explained by paying attention to the fact that prospective teachers do not have sufficient and positive experiences to develop their spatial abilities beginning from preschool education to higher education. Thus, some researchers (Hoffer \& Hoffer, 1992; McGee, 1979; Yurt, 2014) argued that 
practices and experiences regarding the development of spatial abilities have not been sufficiently included in the curricula of public schools. Studies conducted in Turkey are consistent with this premise. Previous research found out that the outcomes and activities incorporated into primary and secondary school curricula are not sufficient to develop spatial thinking ability (Kayhan 2005; Kakmac1, 2009; Turğut, 2007; Yurt, 2014). In order to develop students' spatial thinking abilities, the outcomes specified in the curricula must be enriched beginning from preschool education. In addition, it is seen that studies at the university level aimed at developing spatial ability have been concentrated STEM students (Uttal et al., 2013). Spatial ability, which is used in daily life and in various fields, is quite important for many disciplines. In this vein, the number of studies intended to develop the spatial abilities of teachers and preservice teachers should be increased.

According to the results obtained from the study, it was found that the mental rotation abilities of male prospective teachers were higher compared to female prospective teachers; however, the spatial visualization ability did not vary by gender. When the prospective teachers' opinions concerning spatial ability tests were examined, findings were encountered that supported this result. Indeed, it was seen that compared with the female prospective teachers, the male prospective teachers' opinions with regard to the mental rotation test focused more on the facility of the test and that the perceptions of the female prospective teachers concerning this test concentrated generally on the difficulty of the test. When female and male prospective teachers' opinions with respect to the surface development test were examined, it was found that the opinions of the female and female prospective teachers concerning this test were similar to one another and that both sexes stated that the test was difficult. The results obtained are in parallel with the findings of meta-analyses investigating gender differences in spatial ability. In the meta-analyses studies conducted, it was found that gender variation (difference) was more prominent in mental rotation compared with the other components of the spatial ability (Voyer, Voyer, \& Bryden, 1995 ) and this difference began in the early years of life and continued throughout life (Linn \& Petersen, 1985). It was pointed out that gender differences arising in spatial ability might develop on the basis of biological factors (Burton, Henninger, \& Hafetz, 2005), strategies used (Jordan, Wuestenberg, Heinze, Peters, \& Jaencke, 2002), personal experiences (Ginn\&Pickens, 2005), motivational beliefs (Moè, 2009) and socio-cultural factors (Carnoldi \& Vecchi, 2004; Halpern, 2011). It can be said that especially socio-cultural factors in our country have a great part to play in the development of gender differences in spatial ability. In society, gender is regarded as an important factor in the job definitions made on the basis of sociocultural factors. For example, some professions such as engineering and nursing may be perceived as either male or female professions. Due to this, individuals are directed towards different activities from an early age and gain different experiences. 
This situation may lead to the development of different abilities in girls and boys and to the emergence of gender differences in some areas of competence (spatial ability).

The students' spatial visualization and mental rotation abilities were also investigated according to their academic achievements in the study. It was understood that spatial visualization and mental rotation abilities were correlated with academic average and that spatial visualization and mental rotation abilities of the prospective teachers with high academic achievements were higher. In the relevant literature, studies conducted in different disciplines such as Physics (Kozhevnikov, Motes, \& Hegarty, 2007; Delialioğlu \& Aşkar, 1999), Chemistry (Stieff, Ryu, Dixon, \& Hegarty, 2012; Wu \& Shah, 2004), Mathematics (Casey, Nutall, \& Pezaris, 2001; Cheng \& Mix, 2014; Kyttälä, Aunio, Lehto, Van Luit, \& Hautamäki, 2003; Yurt, 2014) and Geometry (Battista, 1990; Hannafin, Truxaw, Vermillion, \& Liu, 2008) support the results obtained in this study. On the basis of all these results, it can be said that success in many different disciplines is correlated with spatial ability. Individuals who are competent in spatial ability can visualize problems, picture verbal problems in their minds, can easily retain geometric shapes in their minds and easily comprehend the relationships between two and three-dimensional shapes (Carroll, 1993; Kimura, 1999; Lohman, 1996; Patkin, 2015). Undoubtedly, this situation may affect individuals' achievements in different school subjects positively.

In a meta-analysis study, Uttal et al. (2013) revealed that spatial ability could be improved through education. Moreover, Newcombe (2013) pointed out that gender differences seen in spatial ability could be reduced accurate and effective teaching practices. It is seen in the relevant literature that in order to improve the spatial abilities of individuals receiving education at different levels, visual environments (computer programs) and concrete objects (snap-on cubes, tridio etc.) were used (Rafi, Samsudin, \& Ismail, 2006; Y1ld1z, 2009; Yurt \& Sünbül, 2012), drawing activities (Field, 1994; Olkun, 2003) and sport activities (Moreau, Clerc, Mansy-Dannay, \& Guerrien, 2012; Pietsch \& Jansen, 2012) were held. When the curricula of education faculties are examined, it is seen that the number of courses (eg. material development course) that include this kind of activities is quite limited. Prospective teachers' spatial abilities can be improved through elective courses involving these activities.

With developing technology, many virtual tools/applications such as Quest Atlantis (Barab, Thomas, Dodge, Carteaux, \& Tuzun, 2005), virtual museums (Horton, 2006) and Google Earth (Haslett, 2009), which can be used in learning environments, have been designed. Integrating these tools into social studies courses can contribute to developing prospective teachers' spatial thinking abilities. For example, using virtual museums in Archeology and Anthropology courses in Social Studies Teaching undergraduate program curriculum to teach cultural heritage and 
the effects of cultural heritage on human life can make a difference in developing spatial thinking ability. Likewise, Google Earth applications can be used in General Physical Geography courses. This will help students to see three-dimensional field models which they visualize in their mind, to find ways, to give directions, and to calculate the height profile of a place easily.

\section{References}

Barab, S., Thomas, M., Dodge, T., Carteaux, R., \& Tuzun, H. (2005). Making learning fun: Quest Atlantis, a game without guns. Educational Technology Research and Development, 53(1), 86-107.

Battista, M. T. (1990). Spatial visualization and gender differences in high school geometry. Journal for research in mathematics education, 21(4), 47-60.

Battista, M., Wheatley, G., \& Talsma, G. (1982). Spatial visualization, formal reasoning, and geometric problem solving strategies of preservice elementary teachers. Focus on Learning Problems in Mathematics 11(4), 17-30.

Bulut, S., \& Köroğlu, S. (2000). On birinci sınıf öğrencilerinin ve matematik öğretmen adaylarının uzaysal yeteneklerinin incelenmesi [Investigation of spatial abilities of 11th grade students and mathematics prospective teachers]. Hacettepe Üniversitesi Eğitim Fakültesi Dergisi, 18(18), 56-61.

Burton, L. A., Henninger, D., \& Hafetz, J. (2005). Gender differences in relationsof mental rotation, verbal fluency, and SAT scores to finger length ratios ashormonal indexes. Developmental Neuropsychology, 28(1), 493-505.

Büyüköztürk, Ş., Çakmak, E. K., Akgün, Ö. E., Karadeniz, Ş., \& Demirel, F. (2012). Bilimsel araştırma yöntemleri [Scientific research methods]. Ankara, Turkey: Pegem Akademi Yayınları.

Cantürk-Günhan, B., Turgut, M., \& Y1lmaz, S. (2009). Spatial ability of a mathematics teacher: The case of Oya. IBSU Scientific Journal, 3(1), 151-158.

Carnoldi, C., \& Vecchi, T. (2004). Visuo-spatial working memory and individual differences. New York, NY: Psychology Press.

Carroll, J. B. (1993). Human cognitive abilities: A survey of factor analytic studies. Cambridge: Cambridge University Press.

Casey, M. B., Nutall, R. L., \& Pezaris, E. (2001). Spatial-mechanical reasoning skills versus mathematics self-confidence as mediators of gender differences on mathematics subtests using cross national gender based items. Journal for Research in Mathematics Education, $32(10), 28-57$.

Cheng, Y. L., \& Mix, K. S. (2014). Spatial training improves children's mathematics ability. Journal of Cognition and Development, 15(1), 2-11.

Clements, D. H., \& Michael T. B. (1992). Geometry and spatial reasoning. In D. A. Grouws (Ed.), Handbook of research on mathematics teaching and learning (pp. 420-464). New York, NY: Macmillan Publishing Company.

Cohen, J. (1988). Statistical Power Analysis for the Behavioral Sciences (2nd ed.). Hillsdale, NJ: Lawrence Earlbaum Associates.

Contero, M., Naya, F., Saorin, J. L., \& Conesa, J. (2005). Improving visualization skills in engineering education. Computer Graphics and Applications, IEEE, 25(5), 24-31. 
Creswell, J. W. (2012). Educational research: Planning, conducting, and evaluating quantitative and qualitative research. Boston, MA: Pearson Education.

Delialioğlu, Ö., \& Aşkar, P. (1999). Contribution of students' mathematical skills and spatial ability of achievement in secondary school physics. Hacettepe Üniversitesi Eğitim Fakültesi Dergisi, 16(16), 34-39.

Ekstrom, R. B., French, J. W., Harman, H. H., \& Dermen, D. (1976). Manual for kit of factorreferenced cognitive tests (pp. 109-113). Princeton, NJ: Educational testing service.

Field, B. W. (1994). A course in spatial visualization. Journal for Geometry and Graphics, 3(2), 201-209.

George, D., \& Mallery, P. (2003). SPSS for windows step by step: A simple guide and reference. Boston, MA: Allyn \& Bacon.

Ginn, S. R., \& Pickens, S. J. (2005). Relationships between spatial activities and scores on the mental rotation test as a function of sex. Perceptual and Motor Skills, 100(3), 877-881.

Göktepe, S., \& Özdemir, A. Ş. (2013). İlköğretim matematik öğretmen adaylarının uzamsal görselleştirme becerilerinin SOLO modeli ile incelenmesi [Examing elementary mathematics teacher candidates' special visualization skills by solo model]. Kalem Ĕgitim ve İnsan Bilimleri Dergisi, 3(2), 91-146.

Güler, A., Halıcıoğlu, M. B., \& Taşğın, S. (2013). Sosyal bilimlerde nitel araştırma yöntemleri [Qualitative research methods in the social sciences]. Ankara, Turkey: Seçkin Yayıncılık.

Halpern, D. F. (2011). Sex differences in cognitive abilities (4th ed.). Mahwah: Erlbaum.

Hannafin, R. D., Truxaw, M. P., Vermillion, J. R., \& Liu, Y. (2008). Effects of spatial ability and instructional program on geometry achievement. The Journal of Educational Research, 101(3), 148-157.

Haslett, S. K. (2009). Prior use of google earth by undergraduate geography students. Learning and teaching in Geography, Earth and Environmental Sciences (GEES), 22(1), 43-47.

Hegarty, M., \& Kozhevnikov, M. (1999). Types of visual-spatial representations and mathematical problem solving. Journal of educational psychology, 91(4), 684-689.

Hoffer, A. R., \& Hoffer, S. A. K. (1992). Geometry and visual thinking. In T. R. Post (Ed.), Teaching mathematics in grades $K-8$ : Research-based methods (2nd ed.). Boston, MA: Allyn and Bacon.

Horton, W. (2006). E-learning by design. New Jersey, NJ: John Wiley and Sons.

Jordan, K., Wuestenberg, T., Heinze, H. J., Peters, M., \& Jaencke, L. (2002).Women and men exhibit different cortical activation patterns during mentalrotation tasks. Neuropsychologia, 40(13), 2397-2408.

Kakmacı, Ö. (2009). Altıncı sınıf öğrencilerinin uzamsal görselleştirme başarılarının bazı değişkenler açısindan incelenmesi [Investigation of the sixth grade students' spatial visualization success in terms of some variables] (Master's thesis, Eskişehir Osmangazi University, Eskişehir, Turkey). Retrieved from http://tez2.yok.gov.tr/UlusalTezMerkezi/

Karaaslan, G. (2013). Geometri dersine yönelik dinamik geometri yazllımlarlyla hazırlanan etkinliklerin öğrencilerin akademik başarısı ve uzamsal yetenekleri bağlamında incelenmesi [The evaluation of the tasks that were prepared with the dynamic geometry softwares for geometry class in the context of students' academic achievement and spatial abilities] (Master's thesis, Marmara University, İstanbul, Turkey). Retrieved from http://tez2.yok. gov.tr/UlusalTezMerkezi/ 
Kayhan, E. B. (2005). Investigation of high school students' spatial ability (Master's thesis, Middle East Technical University, Ankara, Turkey). Retrieved from http://tez2.yok.gov.tr/ UlusalTezMerkezi/

Kimura, D. (1999). Sex and cognition. Cambridge: MIT Press.

Kozhevnikov, M., Motes, M. A., Rasch, B., \& Blajenkova, O. (2006). Perspective $\square$ taking vs. mental rotation transformations and how they predict spatial navigation performance. Applied Cognitive Psychology, 20(3), 397-417.

Kozhevnikov, M., Motes, M., \& Hegarty, M. (2007). Spatial visualization in physics problem solving. Cognitive Science, 31(4), 549-579.

Kragten, M., Admiraal, W., \& Rijlaarsdam, G. (2015). Students' Ability to Solve Process-diagram Problems in Secondary Biology Education. Journal of Biological Education, 49(1), 91-103.

Kyttälä, M., Aunio, P., Lehto, J. E., Van Luit, J., \& Hautamäki, J. (2003). Visuospatial working memory and early numeracy. Educational and Child Psychology, 20(3), 65-76.

Linn, M. C., \& Petersen, A. C. (1985). Emergence and characterization of sex differences in spatial ability: A meta-analysis. Child Development, 56(6), 1479-1498.

Lohman, D. F. (1996). Spatial ability and g. In I. Dennis \& P. Tapsfield (Eds.), Human abilities: Their nature and measurement (pp. 97-116). Hillsdale, NJ: Erlbaum.

Lubinski, D. (2010). Spatial ability and STEM: A sleeping giant for talent identification and development. Personality and Individual Differences, 49(4), 344-351.

Maeda, Y., \& Yoon, S. Y. (2013). A meta-analysis on gender differences in mental rotation ability measured by the Purdue spatial visualization tests: Visualization of rotations (PSVT: R). Educational Psychology Review, 25(1), 69-94.

Malinowski, J. C. (2001). Mental rotation and real-world wayfinding. Perceptual and Motor Skills, 92(1), 19-30.

McGee, M. G. (1979). Human spatial abilities: Sources of sex differences. New York, NY: Praeger.

Merriam, S. B. (2013). Nitel araştırma desen ve uygulama için bir rehber [Qualitative research a guide to design and implementation]. Ankara, Turkey: Nobel Akademi Yayıncılık.

Ministry of National Education. (2005). İlköğretim (6-8. sinıflar) sosyal bilgiler dersi öğretim programı ve kılavuzu [Primary (6-8. Classes) social studies curriculum and manual]. Ankara, Turkey: Devlet Kitapları Müdürlüğü Basım Evi.

Moè, A. (2009). Are males always better than females in mental rotation? Exploring a gender belief explanation. Learning and Individual Differences, 19(1), 21-27.

Moreau, D., Clerc, J., Mansy-Dannay, A., \& Guerrien, A. (2012). Enhancing spatial ability through sport practice: Evidence for an effect of motor training on mental rotation performance. Journal of Individual Differences, 33(2), 83-88.

National Research Council. (2006). Learning to think spatially: GIS as a support system in the K-12 curriculum. Washington, DC: National Academies Press.

Newcombe, N. S. (2013). Seeing relationships: Using spatial thinking to teach science, mathematics, and social studies. American Educator, 37(1), 26-31.

Olkun, S. (2003). Making connections: Improving spatial abilities with engineering drawing activities. International Journal of Mathematics Teaching and Learning, 3(1), 1-10.

Patkin, D. (2015). Various ways of inculcating new solid geometry concepts. International Journal of Education in Mathematics, Science and Technology, 3(2), 140-154. 
Peng, A. \& Sollervall, H. (2014). Primary school students' spatial orientation strategies in an outdoor learning activity supported by mobile technologies. International Journal of Education in Mathematics, Science and Technology, 2(4), 246-256.

Peters, M., Laeng, B., Latham, K., Jackson, M., Zaiyouna, R., \& Richardson, C. (1995). A redrawn Vandenberg and Kuse mental rotations test: Different versions and factors that affect performance. Brain and Cognition, 28, 39-58.

Pietsch, S., \& Jansen, P. (2012). Different mental rotation performance in students of music, sport and education. Learning and Individual Differences, 22(1), 159-163.

Rafi, A., Samsudin, K. A., \& Ismail, A. (2006). On improving spatial ability though computermediated engineering drawing instruction. Educational Technology \& Society, 9(3), 149-159.

Reilly, D., \& Neumann, D. L. (2013). Gender-role differences in spatial ability: A metaanalytic review. Sex Roles, 68(9), 521-535.

Smith, M. E. (2009). The correlation between a pre-engineering student's spatial ability and achievement in an electronics fundamentals course (Doctoral dissertation, Engineering and Technology Education Department). Retrieved from http://digitalcommons.usu.edu/etd/254

Stieff, M., Ryu, M., Dixon, B., \& Hegarty, M. (2012). The role of spatial ability and strategy preference for spatial problem solving in organic chemistry. Journal of Chemical Education, 89(7), 854-859.

Suter, W. N. (2006). Introduction to educational research: A critical thinking approach. Thousand Oaks, CA: Sage.

Turğut, M. (2007). İlköğretim 2. kademe öğrencilerinin uzamsal yeteneklerinin incelenmesi [Investigation of 6, 7 and 8 grade students' spatial ability] (Master's thesis, Dokuz Eylül University, İzmir, Turkey). Retrieved from http://tez2.yok.gov.tr/UlusalTezMerkezi/

Turğut, M., \& Yenilmez, K. (2012). Matematik öğretmeni adaylarının uzamsal görselleştirme becerileri [Spatial visualization abilities of preservice mathematics teachers]. Eğitim ve Öğretim Araştırmaları Dergisi, 1(2), 243-252.

Turgut, M., \& Yilmaz, S. (2012). Relationships among preservice primary mathematics teachers' gender, academic success and spatial ability. International Journal of Instruction, 5(2), 5-20.

Unal, H., Jakubowski, E., \& Corey, D. (2009). Differences in learning geometry among high and low spatial ability pre-service mathematics teachers. International Journal of Mathematical Education in Science and Technology, 40(8), 997-1012.

Uttal, D. H., \& Cohen, C. A. (2012). Spatial thinking and STEM education: When, why and how. Psychology of learning and motivation, 57, 147-181.

Uttal, D. H., Meadow, N. G., Tipton, E., Hand, L. L., Alden, A. R., Warren, C., \& Newcombe, N. S. (2013). The malleability of spatial skills: a meta-analysis of training studies. Psychological bulletin, 139(2), 352-402.

Voyer, D., Voyer, S., \& Bryden, M. P. (1995). Magnitude of sex differences in spatial abilities: A meta-analysis and consideration of critical variables. Psychological Bulletin, 117(2), 250-270.

Wu, H., \& Shah, P. (2004). Exploring visuospatial thinking in chemistry learning. Science Education, 88(3), 465-492.

Yıldırım, A. \& Şimşek, H. (2011). Sosyal bilimlerde nitel araştırma yöntemleri [Qualitative research methods in social sciences]. Ankara, Turkey: Seçkin Yayıncılık. 
Yıldız, B. (2009). Üç-boyutlu ortam ve somut materyal kullanımının uzamsal görselleştirme ve zihinde döndürme becerilerine etkileri [The effects of using three-dimensional virtual environments and concrete manipulatives on spatial visualisation and mental rotation abilities] (Master's thesis, Hacettepe University, Ankara, Turkey). Retrieved from http:// tez2.yok.gov.tr/UlusalTezMerkezi/

Yurt, E. (2014). Sekizinci sınıf öğrencilerinin matematik başarılarını açıklayan bir yapısal essitlik modeli [A structural equation model explaining the mathematics achievements of the 8th grade students] (Doctoral dissertation, Necmettin Erbakan University, Konya, Turkey). Retrieved from http://tez2.yok.gov.tr/UlusalTezMerkezi/

Yurt, E., \& Sünbül, A. M. (2011, April). Eğitim fakültesi öğrencilerinin uzamsal yeteneklerinin incelenmesi (Selçuk Üniversitesi A. K. Eğitim Fakültesi örneği) [Investigation of education faculty students' spatial abilities A. K. education faculty pattern]. Paper presented at the II. International Conference on New Trends in Education and Their Implications, Antalya, Turkey.

Yurt, E., \& Sunbul, A. M. (2012). Effect of modeling-based activities developed using virtual environments and concrete objects on spatial thinking and mental rotation skills. Educational Sciences: Theory and Practice, 12, 1987-1992. 